\title{
Development of Fourth Industry Oriented Mechanical Engineering Mechatronics Learning Devices 4.0
}

\author{
Hefri Hamid ${ }^{*}$, Nizwardi Jalinus², Azwar Inra3 ${ }^{3}$, Ambiyar $^{4}$, Waskito ${ }^{5}$, Sukardi ${ }^{6}$, Niny \\ Herlin $^{7}$
}

1,2,3,4,5,6 Departement of Engineering Faculty Padang State University, Padang, West Sumatra, Indonesia

${ }^{7}$ Department of Physic Faculty Indonesia University, Jakarta, West Jawa, Indonesia

\section{A R T I C L E I N F 0}

Article history:

Received 15 August 2019

Received in revised

Form 29 September 2019

Accepted 18 October 2019

Available online 29

November 2019

Keywords:

Development of learning devices, Mechatronics , I

DI Model, Modern

Industrial Work Ability

\section{A B S T R A C T}

The ability of modern industrial work must be mastered by vocational engineering students, therefore it is important to develop learning tools that are oriented to the fourth industry. This study assesses the development of mechatronics learning tools that are arranged based on the abilities that must be possessed by students to work in the fourth industrial era using the IDI model. Data was collected from the validity, practicality and effectiveness tests on the programmed subjects in 2019. Learning activities carried out during 16 meetings to produce a smart factory (prototype). Analysis shows that learning tools are developedit is valid, then the response of teaching staff shows the criteria are very practical and based on the response of students also in the category of very practical. The findings, an increase in students' understanding of the value of the end of the semester, but they have to struggle even more to obtain more optimal results. Besides, the learning device also forms the general ability of the learner, the learning communicative, collaborative, innovative, creative, leadership and entrepreneurship that observed during the process of learning to walk . 


\section{Introduction}

Industrial companies are now experiencing changes in conditions in various challenges for employment, as well as education that must be encouraged to adapt to environmental changes (Abele et al, 2017). Recently, many studies have offered that education be adapted to industrial changes (Enke et al, 2019; Andresen et al, 2019; Mavrikios et al, 2019), especially for changes in the fourth industrial production pathway (i4.0) which demands new competencies to enter in job qualifications in the company (Schallock et al, 2018; Rauch et al, 2019; Muller-frommeyer et al, 2017). Vocational engineering education plays a major role in changing competencies in modern industrial production (Elbestawi et al, 2018). This can be seen from the purpose of technical education in preparing skills and skills training for students to enter the workforce, namely industrial companies and be able to develop themselves in the field. Vocational technical education must adapt to this new challenge.

Vocational technical education must respond to the above by integrating new competencies into the existing curriculum (Enke et al, 2019). Designing learning to be oriented towards new competencies can be done by developing learning methods and tools (Teichmann, 2019). This makes it faster and easier to do even greater changes in new competencies that are targeted as structures, organizations, technical, didactic learning processes (Balve and Ebert, 2019).

In special studies, mechatronics learning competence in one of the universities is not currently possible to support work skills in the modern era. The green point is the fourth industrial era. Mechatronic learning competencies previously focused on the control system in place. Whereas the industry has developed with integrated production systems through long distance relationships (internet of things), artificial intelligence and smart production factories (Inkermann et al, 2019; Buchi, 2020). To achieve the competence of engineering students in the field of mechatronics that can integrate work skills in the fourth industrial era it is important to develop learning devices.

\section{A. Problem Statement}

Current learning competencies should be integrated with the ability to work in the luxury industry . However, little work skills in industries developed for learning tools in higher education (Enke et al, 2019). The result will have an impact on unemployment. In small groups, especially mechanical engineering education, mechatronics courses are very important for developing valid, practical and effective learning tools for work skills in the current industrial era, because work skills in the industry today have experienced many changes to the use of automation systems, the internet of things, big data, simulations, augmentet reality, claud computing, additive manufacturing and integrated systems (Ghobakhloo, 2019).

\section{B. Objective Research}

The research aims to connect the ability to work in the fourth industrial era with the competence of mechanical engineering mechatronics learning through the development of learning devices. This activity is carried out to see the results of development during 16 meetings (one semester). This learning tool produces a syllabus, learning program unit, teaching materials and learning videos that are integrated with learning materials to have the ability to work fourth industry.

\section{Methods}

The research methodology used is research and development with the Instructional Development Institute (IDI) model Gustafson \& Branch, (1997: 60) .

This stage is carried out identification and analysis of work capabilities in modern industry. Then do the identification and analysis of learning characteristics of students. Determine learning outcomes for the fourth industry-oriented. 


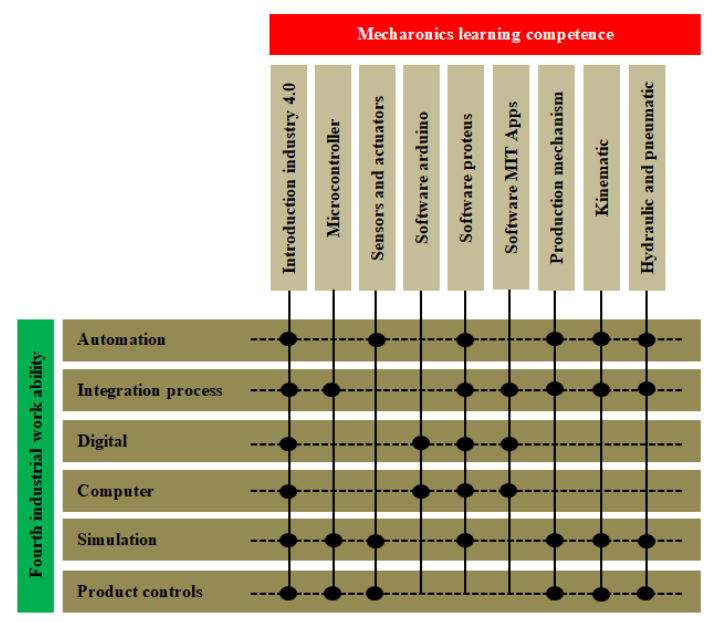

Figure. 1. Relationship of Industrial Work Ability with Mechatronics Learning Outcome

This stage is carried out the preparation of the syllabus and learning unit related to the ability of attitude, knowledge and skills. Then compile learning material for one semester. So on making instructional media and learning videos.

This stage is carried out to assess the learning device, then an assessment analysis is carried out and analyzed to conclude the results of the development of the learning device.

Students of the Faculty of Engineering majoring in mechanical engineering in mechatronics courses at the State University of Padang-Indonesia 2019 school year are the population in this study. For the research sample, students are enrolled in the mechanical engineering department namely; $n=30$. This research was conducted after getting an appointment, time of implementation and agreement with the Department of Mechanical Engineering, Faculty of Engineering .

This research is a course activity to develop a fourth industry-oriented learning device. This course is taught for the local content in view of the later development of $n$ will be used for other local. The first meeting of the pursuers introduces the relationship between mechatronic learning and modern industrial work skills, then instructs the next learning with discussion through medium groups ( 5 to 6 students).

The second meeting to the last meeting students are given teaching materials and learning videos to produce the fourth industrial orientation product. In the learning process they are assigned to use various tools to practice the knowledge they have gained from the learning modules and videos.

The media used are ATmega 328 microcontroller, sensors and actuators, power supplies. For computer program, faculty provide software arduino, Proteus 8, MIT inventors 2 and roboDK to produce learning outcomes in accordance with the fourth industrial work ability (Stock et al, 2018). Assessment of learning outcomes is made based on indicators of learning outcomes consisting of 30 items. Then ask the teaching staff to see the impact caused by the questionnaire.

Students are tasked with finding and planning an intelligent plant pathway system that is appropriate for the environment and business and industry. Task planning is discussed based on the team and integrating it into discourse groups. This is done so that communicative and collaborative relationships occur between discourse groups with the final assignment team. Then ask them to put together a portfolio of papers and a final report on the assignment design. Then, ask students to respond to learning tools developed through a questionnaire.

This research was conducted in the odd semester of 2019 Department of Mechanical Engineering, Faculty of Engineering, State University of Padang. There are three components that will be assessed in this study, namely; validity, practicality and effectiveness of learning tools that have been developed.

To see the suitability of the learning kit with the validation by the expert validator, there are two aspects, namely; clarity of identity, clarity of content for the syllabus and learning unit. Then the four aspects of teaching materials are; format clarity, image clarity, language accuracy and display interest. Furthermore, six aspects of instructional video media are; content suitability, display interest, sound clarity, image clarity, language accuracy and clarity of description. Then, for learning material using three aspects namely; concept suitability, suitability of subject output and adequacy of study material. Validators are asked to fill out questionnaires according to the validation aspects by using a ranking scale of 1 to 5 . 
To see the response of the instructor to the learning media used in the learning process, there are three aspects namely; ease of using media, ease of understanding material and media usefulness. Then the responses given by students to the learning media, there are three aspects, namely; ease of use of learning media, ease of understanding, increase attractiveness, usefulness of learning media.

To see the effect of the use of the developed learning tools is done by assessing learning outcomes before and after the learning process is carried out.

The validity of the learning kit is analyzed using the Aiken's V Statistics formulation, namely;

$$
\mathrm{V}=\sum \mathrm{s} /[\mathrm{n}(\mathrm{c}-1)]
$$

The range used in this validation is $\geq 0.66$ with a distance of 0 to 1 . For the validity of the questions is done by testing the questions through the validity of the construction based on the examination of teaching staff, the functioning of the deception with a condition of at least $5 \%$ of the number of students taking the test, the level difficulty of questions by comparing the number of correct answers with the sum of all test takers then classifying them into the form of difficulty idek where the category $0.30 \leq \mathrm{P} \leq 0.70$ can be used for the next test, the item test uses the biserial point correlation formula and the reliability of the questions using the Kuder Richardson formula 20 (KR-20) .

The practicality of instructional media is analyzed using weighting values with a range of 0 to 100 . Then the learning outcomes are analyzed using the t test to get the significance price and compare it with the $\mathrm{r}$ table value for making decisions.

\section{Result And Discussion}

Table 1. Validity assessment

\begin{tabular}{|c|c|c|c|c|c|c|c|c|}
\hline \multirow{2}{*}{$\mathbf{N}$} & \multirow{2}{*}{$\begin{array}{l}\text { Development } \\
\text { Componen }\end{array}$} & \multicolumn{3}{|c|}{ Validator } & \multirow{2}{*}{ E Item } & \multirow{2}{*}{$N(C-1)$} & \multirow{2}{*}{ Value V } & \multirow{2}{*}{ Information } \\
\hline & & 1 & 2 & 3 & & & & \\
\hline 1 & Syllabus & 0,91 & 0,84 & 0,93 & 26 & 104 & 0,89 & Valid \\
\hline 2 & Learning Unit & 0,90 & 0,88 & 0,91 & 26 & 104 & 0,90 & Valid \\
\hline 3 & Teaching Materials & 0,85 & 0,84 & 0,95 & 20 & 80 & 0,88 & Valid \\
\hline 4 & Tutorial Video & 0,89 & 0,85 & 0,87 & 22 & 88 & 0,87 & Valid \\
\hline 5 & Studi Material & 0,88 & 0,97 & 0,80 & 19 & 76 & 0,88 & Valid \\
\hline
\end{tabular}

\section{Responsesto Teaching Materials and Learning Video}

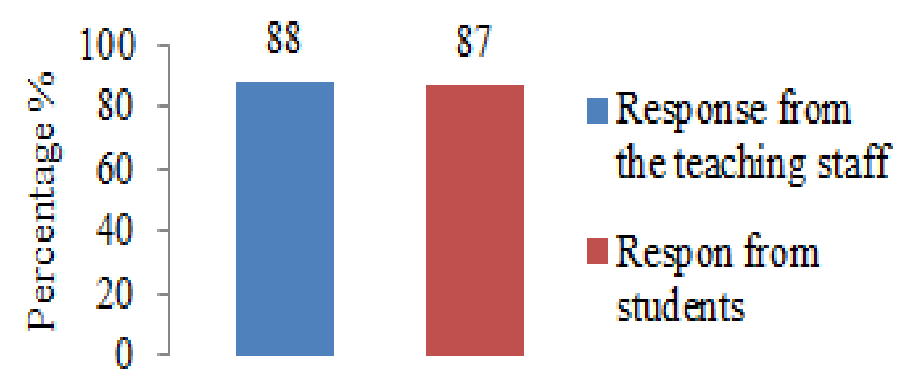

Figure 2. Assessment Based on Response 


\section{Assessment of Learning Outcome}

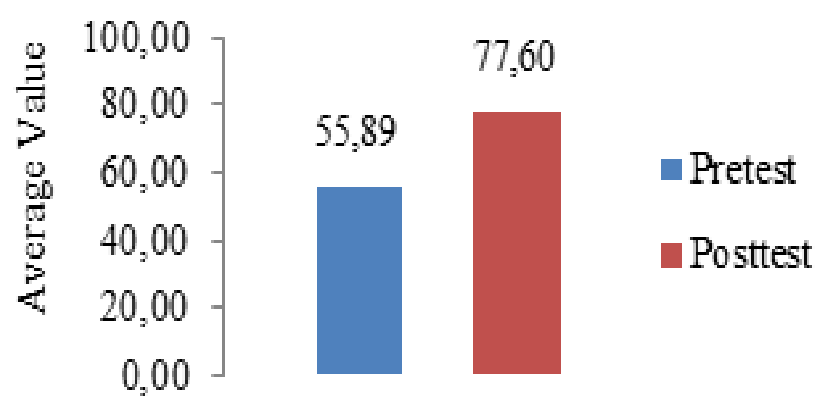

Figure 3. Final Learning Assessment (Posstest)
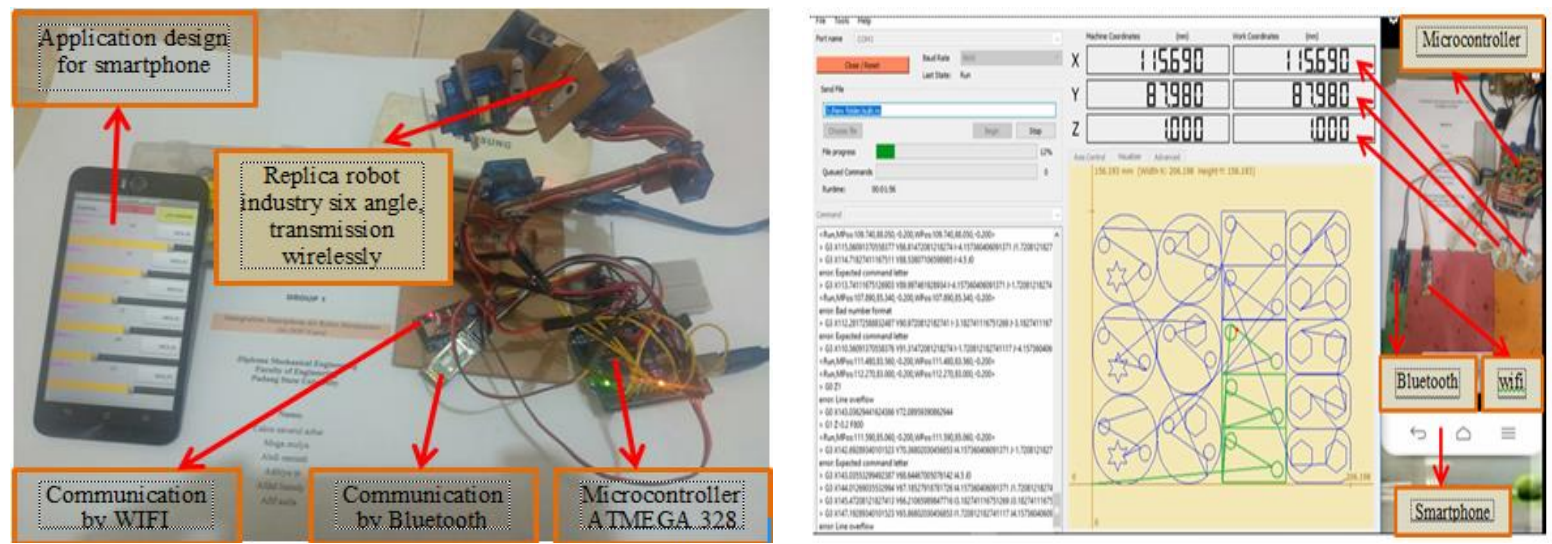

Figure 4. Learning Outcomes for Modern Industrial Work Abilities in Smart Process Factories.

\section{A. Final Learning Assessment}

Developing learning tools through the IDI model to have work skills in the fourth industrial era can improve students' understanding and reasoning. The results obtained from the learning process show an increase in the value of the end of the semester. For the average learning outcomes before treatment (pretest) of 55,89 and after being given a treatment (posttest) of 77,80. The possibility of increasing the value of the end of the semester, because it uses instructional media and learning video tutorials that can be used by students to understand learning materials. The relationship between learning tools developed with learning media can provide the convenience of mechanical engineering mechatronics students in the learning process and can also reduce their stress on the achievement of specified learning outcomes (Thomas et al, 2018).

In the process of learning to use Mechatronics learning tools Mechanical-oriented fourth industry also looks the character of students in communicative abilities. They are more likely to unite ideas and ideas in building a realistic concept with learning material. This is consistent with the results of the study (Pehrson et al, 2016; Sallati et al, 2019) that the development of learning tools positively affects the communication skills of learners in the learning process. However, based on their portfolio report they are weak to find information that is relevant and accurate to what they are discussing, students are more focused on the media sources provided by the pursuers. In accordance with the opinion (Rust et al, 2019) that the weak skills of students to find sources that are relevant and accurate in doing portfolio work.

In addition, researchers also found that they are more familiar with each other to work together, help each other, complement each other, tolerant and optimistic. Working in group form for the same purpose, even terjalinya a good relationship with the students majoring in engineering who else her. Thus it can be interpreted that this learning tool can make students to collaborate knowledge. This is also supported by several researchers that to optimize student learning outcomes can be done by designing collaborative learning (Lam and Muldner, 2017; Yap et al, 2017; Zhang and Cui, 2018; Hill et al, 2020).

But no less important than themselves is the growth of a new spirit, to produce the fourth industrial orientation product in Mechatronics learning. Students are more likely to become a creator in developing ideas and ideas. Even they respond to technological developments in their environment, this 
can be seen from their optimism to make intelligent devices/machines integrated with smartphones. In line with the opinion (Richardson \& Mishra, 2017) that the success of learning is influenced by the creativity of students. In line with the phrase Yakimov \& lovev, (2019) that students are actively involved in the selection of tasks that can provide a loophole for them to be creative even though they are involved in special content in learning.

Then, researchers also get a direct response to their innovation ideas, some creative ideas are proposed for the continuation of learning Mechanical Mechatronics. One such idea is the maintenance and maintenance of laying hens based on the internet, they plan the process of feeding control, feeding, cleaning and egg production lines as well as the sales process. The concepts offered by students towards their innovation ability are objectively seen as a result of the learning tools developed. Then another idea is an Android-based arm control for concrete pumps, which they see firsthand the work process of a pump aid to deliver fresh concrete to the casting place that they have traditionally considered because it still uses handle control. This is the same as what other researchers have found that the nature of the learning media developed should be able to awaken or foster students' innovation abilities (Mention et al, 2019; Keinnanen et al, 2019).

In addition to the above, researchers also observe students' leadership abilities. The ability of students to influence peers in achieving the objectives of the planned task. The emergence of their leadership abilities in making decisions democratically can be seen from the way they set components to build an idea in the learning task. In simple terms it shows the growth of students' leadership abilities towards the learning process that is developed. Besides that, their leadership also grows towards ideas and ideas on innovative abilities, and even their entrepreneurial interest grows from the planned concepts. In accordance with the opinion (Weber, 2019) that learning design influences their leadership attitudes towards complex problems. Furthermore, it is reinforced by research (Martin-Rojas et al, 2019) that good learning design can also affect students' entrepreneurial interest.

\section{B. Respon assessment}

Improved student learning outcomes are also influenced by learning media, both from the media given teaching materials and video tutorials. The above is known through responses in the form of a questionnaire given to students after the learning process, so that the results obtained based on student responses of $87 \%$ which are in very practical criteria. Thus the learning media created in developing learning tools can help students to understand learning material and can also maximize the learning process. In line with the opinion (Al-Mamun et al, 2020) that teaching materials/modules can help students to understand learning material more optimally, directed, structured and independent. Then (Reining, 2019) said that instructional video media from YouTube has the potential to improve students' reasoning. This is also reinforced by (Uzun \& Kilis, 2018) that to improve students' understanding must be supported by a sensing system (especially for the sense of sight).

Mechatronics Engineering learning media developed can also help instructors in maximizing the time of the learning process in the local area, because the instructional material/module media is distributed to students that can be used for learning outside the classroom, in addition to YouTube video learning equipment mechatronics engineering videos also provides access to connect with students so they can communicate. In accordance with the opinion (Abuatiq, 2019) that learning feedback is very important in the teaching and learning process. This can be interpreted that learning feedback can be done through YouTube video media as communication information. This is evident that the media of teaching materials/modules and instructional videos are very helpful for teaching staff in the teaching and learning process of students, based on the instructors' response to the media used in the Mechanical Engineering Mechatronics learning process by $88 \%$ which is in very practical criteria. \}

\section{Implication}

The results of this study prove that it is very important to develop learning tools for vocational education because of changes in a flexible industrial work environment. We recommend that developed mechatronic learning device is used for the learning process with Honors in engineering so that students have the ability to work in the fourth industrial era and their enhancement the study of students towards learning media provided. Assessment of learning outcomes can be used to create programs and processes of practical learning in vocational education (Rahman et al, 2014). Practical learning programs and processes can be strengthened by including skills learning activities (Choi et al, 2019).

Furthermore, efforts are needed to develop various aspects of work skills assessment in the fourth industrial era. This is done so that students have the abilities and skills integrated with the more modern industrial world. 


\section{Limitation}

The results of this study are students' semester-end assessments of learning tools developed to have work skills in the fourth industrial era. In the future researchers will assess the performance of students in learning practices so they can be compared with what they apply, because skills in the learning process are the result of programmed learning (Rahman et al, 2014).

\section{Conclussion}

This research connects work capabilities in the path of modern production into learning activities to develop Mechanical Engineering Mechatronics learning devices so that the fourth industry is valid, practical and effective. The findings, learning tools developed with the IDI model can improve student learning outcomes with an average pretest value of 55,89\% and at posttest of $77,60 \%$.

The increase in learning outcomes is influenced by the validity of learning devices that have met good requirements, the average validator assessment of learning devices on the syllabus aspect is 0,89 , the SAP aspect is 0,90 , the teaching material aspect is 0,88 , the video aspect is learning amounted to 0,87 and material aspects amounted to 0,88 with an assessment range of 0 to 1 .

Then the increase in learning outcomes is also influenced by the learning media, Mechatronics learning media Mechanical Engineering used is the media of teaching materials/modules and learning videos. The average assessment of students' responses to the learning media used was $87 \%$, besides that the instructors also responded to the Mechatronics learning media with an average of $88 \%$.

The Mechanical Engineering Mechatronics learning tool developed also influences communicative abilities, collaborative abilities, innovative abilities, creative abilities and the ability to lead and be entrepreneurial during the Mechanical Engineering learning process developed.

\section{Reference}

Abele, E., Chryssolouris, G., Sihn, W., Metternicha. J, ElMaraghy, H., Seliger, G., Sivardf, G., ElMaraghy, W., Hummelg, V., Tischa M., \& Seifermanna, S. (2017). Learning factories for future oriented research and education in manufacturing. CIRP Annals Manufacturing Technology 66, 803826. doi: http://dx.doi.org/10.1016/ j.cirp.2017.05.005

Abuatiq, A., PhD, RN. (2019). Development Tools for Evaluating Virtual Patient Learning Systems. Teaching and Learning in Nursing 14, 291297. doi: https://doi.org/10.1016/j.teln.2019.06.010

Awad, A., Al-Haqan, A., \& Moreau, P. (2016). Motivations, career aspirations, and learning experiences of students in the pharmacy program at Kuwait University: A tool to guide curriculum development. Currents in Pharmacy Teaching and Learning, doi: http://dx.doi.org/10.1016/j.cptl.2016.11.018

Al-Mamun, Md.A., Lawrie, G., \& Wright, T. (2020). Instructional design of scaffolded online learning modules for self directed and inquiry-based learning environments. Computers \& Education 144, 103695. doi: https://doi.org/10.1016/j.compedu.2019.103695

Andresen, A., Bruneo, TM, \& Nielsen, K. (2019). Engineering Education in Changeable and Reconfigurable Manufacturing: Using Problem-Based Learning in a Learning Factory Environment. $52^{\text {nd }}$ CIRP Conference on Manufacturing Systems Engineering, Procedia CIRP 81, 7-12. do i: 10.1016 / j.procir.2019.03.002

Balve, P., \& Eberta, L. (2019). Ex Post Evaluation of a Learning Factory-Competence Development Based on Graduates Feedback. 9th Conference on Learning Factories, Procedia Manufacturing 31 813. doi: 10.1016 / j.promfg.2019.03.002

Berndtsson, I., Dahlborg, E., \& Pennbrant, S. (2020). Work-integrated learning as a pedagogical tool to integrate theory and practice in nursing education - An integrative literature review. Nurse Education in Practice 42, 102685. doi: https://doi.org/10.1016/j.nepr.2019.102685 
Büchi, G., Cugno, M., \& Castagnoli, R. (2020). Smart factory performance and Industry 4.0. Technological Forecasting \& Social Change 150, 119790. doi: https://doi.org/10.1016/j.techfore.2019.119790

Choi, SJ, Jeong, JC, \& Kim, SN (2019). Impact of vocational education and training on adult skills and employment: An applied multilevel analysis. International Journal of Educational Development 66, 129-138. doi: https://doi.org/10.1016/j.ijedudev.2018.09.007

Elbestawi, M., Centea, D., Singha, I., \& Wanyamaa, T. (2018). SEPT Learning Factory for Industry 4.0 Education and Applied Research. 8th Conference on Learning Factories-Advanced Engineering Education \& Training for Manufacturing Innovation, Procedia Manufacturing 23, 249-254. doi: 10.1016 / j.promfg.2018.04.025

Enke, J., Glass, R., Kre, A., Hambach, J., Tisch, M., \& Metternicha, J. (2018). Industrie 4.0 - Competencies for a modern production system A curriculum for Learning Factories. 8th Conference on Learning Factories-Advanced Engineering Education \& Training for Manufacturing Innovation, Procedia Manufacturing 23, 267-272. doi: 10.1016 / j.promfg.2018.04.028

Ghobakhloo, M. (2019). Industry 4.0, Digitization, and Opportunities for Sustainability. Journal of Cleaner Production S0959-6526 (19) 34739-0. doi: https://doi.org/10.1016/j.jclepro.2019.119869

Gustafson, KL, \& Branch, RM, (1997). Survey of Instructional Development Model, Third Edition. ERIC Clearinghouse On Information And Technology, Syracuse NY. Washington, DC. ISBN 0-937597-430

Hill, R., Woodward, M., \& Arthur, A. (2020). Collaborative Learning in Practice (CLIP): Evaluation of a new $\begin{array}{llll}\text { approach to clinical learning. Nurse Education Today } 85 . & 104295 .\end{array}$ doi: https://doi.org/10.1016/j.nedt.2019.104295

Inkermann, D., Schneider, D., Martin, NL., Lembeck, H., Zhang, J., \& Thiede, S., (2019). A framework to classify Industry 4.0 technologies across production and product development. 29th CIRP Design, Procedia CIRP 84, 973-978. doi: 10.1016 / j.procir.2019.04.218

Karimi, M., \& Dowlatabadi, HR (2014). Authenticity vs. Practicality: Metacognitive Awareness through Authentic materials in EFL classroom. International Conference on Current Trends in ELT, Procedia - Social and Behavioral Sciences 98, 844-851. doi: 10.1016 / j.sbspro.2014.03.490

Keinänen, M., Ursin, J., \& Nissinen, K. (2018). How to measure students' innovation competences in higher education: Evaluation of an assessment tool in authentic learning environments. Studies in Educational Evaluation 58, 30-36. doi: https://doi.org/10.1016/j.stueduc.2018.05.007

Klimova, BF (2014). Evaluation methods as an effective tool for the development of students' learning. Procedia - Social and Behavioral Sciences 152, 112-115. doi: 10.1016 / j.sbspro.2014.09.165

Lam, R., Muldner, K. (2017). Manipulating cognitive engagement in preparation-to-collaborate tasks and the effects on learning. Learning and Instruction 112. doi: http://dx.doi.org/10.1016/j.learninstruc.2017.05.002

Martín-Rojas, R., Garrido-Moreno, A., \& García-Morales VJ (2019). Fostering Corporate Entrepreneurship with the use of social media tools. Journal of Business Research (Retrieved December 27, 2019 from), doi: https://doi.org/10.1016/j.jbusres.2019.11.072

Mavrikios, D., Georgoulias, K., \& Chryssolouris, G. (2019). The Teaching Factory Network: A new collaborative paradigm for manufacturing education.9th Conference on Learning Factories, Procedia Manufacturing 31, 398-403. doi: 10.1016 / j.promfg.2019.03.062 
Mention, A., Barlatier., \& Josserande, E. (2019). Using social media to leverage and develop dynamic capabilities for innovation. Technological Forecasting \& Social Change 144, 242250. doi: https://doi.org/10.1016/j.techfore.2019.03.003

Morris, N., Swinnerton, B., \& Coop, T. (2019). Lecture recordings to support learning: A contested space between students and teachers. Computers \& Education 140, 103604. doi: https://doi.org/10.1016/j.compedu.2019.103604

Müller-Frommeyer, LC, Aymans, SC, Bargmann, C., Kauffeld, S., \& Herrmann, C. (2017). Introducing competency models as a tool for holistic competency development in learning factories: Challenges, examples and future applications. Procedia Manufacturing , 9, 307-314. doi: 10.1016 / j.promfg.2017.04.015

Pehrson, C., Banerjee, SC, Manna, R., Shen, MJ, Hammonds, S., Coyle, N., Krueger, CA, Maloney, E., Zaider, T., Bylund, CL (2016). Responding empathically to patients: Development, implementation, and evaluation of a communication skills training module for oncology nurses. Patient educational and counseling 99, 610-616. doi: http://dx.doi.org/10.1016/j.pec.2015.11.021

Rahman, A., Hanafi, N., Mukhtar, M., \& Ahmad, J. (2014). Assessment of Practices for Competency Based Education and Training in Vocational College, Malaysia. Procedia - Social and Behavioral Science 112, 1070-1076. doi: 10.1016 / j.sbspro.2014.01.1271

Rauch, E., Morandell, F., \& Matt Dominik T. (2019). AD Design Guidelines for Implementing I4.0 Learning Factories.9th Conference on Learning Factories, Procedia Manufacturing 31, 239-244. doi: 10.1016 / j.promfg.2019.03.038

Reed, SJ, DNP, APRN. (2011). Debrieffing Experience Scale: Development of a Tool to Evaluate the Student Learning Experience in Debrieving. Clinical Simulation in Nursing , 8, (6), 211-217. doi: 10.1016 / j.ecns.2011.11.002

Reining, N., Kauffeld, S., \& Christoph, H. (2019). Students' interactions: Using video data as a mean to identify competences Addressed in learning factories. 9th Conference on Learning Factories, Procedia Manufacturing 31, 1-7. doi: 10.1016 / j.promfg.2019.03.001

Richardson, C., \& Mishra, P. (2017). Learning Environments that Support Student Creativity: Developing the SCALE. Thinking Skills and CreativityS1871-1871 6, doi: https://doi.org/10.1016/j.tsc.2017.11.004.

Rust, C., Gentry, WM, \& Ford, H. (2019). Assessment of the e ect of communication skills training on communication apprehension in first year pharmacy students - A two-year study. Currents in Pharmacy Teaching and Learning, (Retrieved December 27, 2019 from), doi: https://doi.org/10.1016/j.cptl.2019.11.007

Sallati, C., Bertazzi, Jd.A., \& Schützer, K. (2019). Professional skills in the Product Development Process: the contribution of learning environments to professional skills in the Industry 4.0 scenario. 29th CIRP Design, Procedia CIRP 84, 203-208. doi: 10.1016 / j.procir.2019.03.214

Schallock, B., Christoffer, R., Roland, J., \& Holger, K. (2018). Learning Factory for Industry 4.0 to provide future skills beyond technical training. 8th Conference on Learning Factories-Advanced Engineering Education \& Training for Manufacturing Innovation, Procedia Manufacturing 2327 32. doi: 10.1016 / j.promfg.2018.03.156

Stock, T., Obenaus, M., Kunz, S., \& Kohl, H. (2018). Industry 4.0 as Enabler for a Sustainable Development: A Qualitative Assessment of its Ecological and Social Potential. Process Safety and Environment Protection S0957-5820 (18) 30367-7. doi: https://doi.org/10.1016/j.psep.2018.06.026 
Teichmann, M., Ullrich, A., \& Gronau, N. (2019). Subject-oriented learning - A new perspective for vocational training in learning factories.9th Conference on Learning Factories, Procedia Manufacturing 31, 72-78. doi: 10.1016 / j.promfg.2019.03.012

Tvengea, N., \& Ogorodnyka, O. (2018). Development of evaluation tools for learning factories in manufacturing education. 8th Conference on Learning Factories 2018 - Advanced Engineering Education \& Training for Manufacturing Innovation, Procedia Manufacturing 23 33-38. doi: 10.1016 / j.promfg.2018.03.157

Thomas, LJ, Parsons, M., Whitcombe, D. (2018). Assessment in Smart Learning Environments: Psychological Factors Affecting Perceived Learning. Computers in Human Behavior S0747-5632 (18) 30572-7. doi: 10.1016 / j.chb.2018.11.037

Uzun, AM, \& Kilis S. (2018). Does Persistent Involvement in Media and Technology Lead To Lower Academic Performance? Evaluating Media End Technology Use in Relation to Multitasking, Self Regulation and Academic Performance. Journal of Computer in Human Behavior, Volume 88, ISSN 0747-5832. doi: 10.1016 / j.chb.2018.08.045

Weber, MR (2019). An exploratory study in student leadership and True Colors personality with learning and training.Journal of Hospitality and Tourism Management 40, 125133. doi: https://doi.org/10.1016/j.jhtm.2019.08.001

Yap, JBH, Abdul-Rahman, H., \& Chen, W. (2017). Collaborative models: Managing design changes with reusable project experiences through project learning and effective communication. International Journal of Project Management 35, 1271. doi: http://dx.doi.org/10.1016/j.ijproman.2017.04.010

1253-

Zhang, J., Cui, Q. (2018). Collaborative Learning in Higher Nursing Education: A Systematic Review. Journal of Professional Nursing, (Retrieved December 27, 2019 from), doi: 10.1016 / j.profnurs.2018.07.007

Yakimov, PI, \& Iovev, AN (2019). Development of a Modern Learning Environment for Education in Mechatronics and Industrial Automation. IFAC Papers On Line 52-25, 441-444. doi: 10.1016 / j.ifacol.2019.12.578 